\title{
Corrosion-cavitation-erosion: surface morphology study of a carbon steel in a multiphasic saline bath
}

Fernando Nunes da Silva ${ }^{1}$, Plínio Melo de Oliveira ${ }^{1}$, Nícolas Matheus da Fonseca Tinoco de Souza Araújo ${ }^{1}$, Eugênio Teixeira de Carvalho Filho ${ }^{1}$, Jardel Dantas da Cunha ${ }^{2}$, Djalma Ribeiro da Silva ${ }^{3}$, João Telésforo Nóbrega de Medeiros ${ }^{1}$

\footnotetext{
${ }^{1}$ Study group of tribology and structural integrity, Federal University of Rio Grande do Norte, Avenue Senador Salgado Filho, S/N. Mailbox 1524, University Campus, Lagoa Nova, CEP: 59072970, Natal, Rio Grande do Norte, Brazil.

${ }^{2}$ Engineering center, Rural Federal University of Semi-Arid, Avenue Francisco Mota, 572, University Campus, Costa e Silva, CEP: 59625900, Mossoró, Rio Grande do Norte, Brazil.

${ }^{3}$ Chemical institute, Federal University of Rio Grande do Norte, Avenue Senador Salgado Filho, 1524, University Campus Lagoa Nova, CEP: 59072970, Natal, Rio Grande do Norte, Brazil. e-mail: nunesdaslva@gmail.com,plinio_rpg@hotmail.com,nicolas.tinoco@hotmail.com,eugenioteixeira_@hotmail.com, jtelesforo@yahoo.com,djalmarib@gmail.com,jardel.dantas@ufersa.edu.br
}

\begin{abstract}
During the production of petroleum and gas, the equipments employed for this activity are subjected to synergetic wear mechanisms, such as corrosion, corrosion-cavitation and corrosion-cavitation-erosion. Laboratory experiments has been performed to reproduce some of these mechanisms, however, sometimes the tests is not capable to recreate the complexities caused by hydrodynamic flows, physico-chemical and mechanical non-linearities. The main objective of this work is to evaluate specimens of low carbon steel under laboratory conditions, such as corrosive, cavitative-corrosive $\left(\mathrm{CO}_{2}\right)$ and corrosive-erosive $\left(\mathrm{CO}_{2}+\right.$ $\left.\mathrm{SiO}_{2}\right)$ environments. During the tests, the specimens were subjected to a stirring aqueous saline solution $(0$ and $5.0 \mathrm{~m} / \mathrm{s}$ ) at two levels of temperature, with gas injection $(5.0 \mathrm{~L} / \mathrm{min})$ and contaminated with by solids particles of $\mathrm{SiO}_{2}(2.5 \%$ mass $)$. The surface of the specimens subjected to upstream flow $\left(0^{\circ}\right.$ in a cylindrical generatrix of the specimen), and downstream flows $\left(180^{\circ}\right)$ were analyzed by profilometry. The measurements of roughness and waviness of all specimens were statistically analyzed at a confidence level of $95 \%$ and significant differences observed in some matrices were discussed. The results suggest that the wear mechanisms that act in the upstream generatrix differ from that of specimen downstream.
\end{abstract}

Keywords: Tribochemistry, Corrosion, Erosion, Cavitation, Surface Texture.

\section{INTRODUCTION}

The production of petroleum in the offshore fields as well as the transportation of petroleum, water, particulate matter and gas, including those associated with the pre-salt layer, has demanded detailed studies about the main wear mechanisms of the materials including those defined as corrosion, corrosion-cavitation and corrosion-cavitation-erosion. It is a complex study. It could be associated with the presence of $\mathrm{O}_{2}, \mathrm{H}_{2} \mathrm{~S}$, $\mathrm{CO}_{2}$, bubble formation and erosion by hard particles, as discussed by Nunes da Silva 0. Besides, this complexity may be increased by the action of microorganisms on the severity of wear rate as well as by the particulate matters such as $\mathrm{CaCO}_{3}, \mathrm{SiO}_{2}$, iron oxides, sulfides and so. Geometric features of particles, flow rates and pressure fields have been studied and modeled to correlate them with valves, equipment and damage to oil pipelines, such as pites, scars, wrinkles/waves, residual stresses, striations, fatigue, as related in several investigations $02-8]$.

The currently accepted $\mathrm{CO}_{2}$ corrosion mechanism involves the hydration of $\mathrm{CO}_{2}$ and formation of $\mathrm{H}_{2} \mathrm{CO}_{3}$. According to Nesic 0 , the cathodic reaction that describes this process is given by:

$$
\mathrm{CO}_{2}+\mathrm{H}_{2} \mathrm{O} \leftrightarrow \mathrm{H}_{2} \mathrm{CO}_{3}
$$


The aqueous corrosion of carbon steel by $\mathrm{CO}_{2}$ is an electrochemical process that involves the anodic dissolution of steel and the cathodic hydrogen evolution 0 . The overall reaction is:

$$
\mathrm{Fe}+\mathrm{CO}_{2}+\mathrm{H}_{2} \mathrm{O} \rightarrow \mathrm{FeCO}_{3}+\mathrm{H}_{2}
$$

Depending on experimental conditions, the $\mathrm{FeCO}_{3}$ forming an uniform layer and the corrosion rate decrease due to the presence of a diffusion barrier for the species involved in the corrosion process and the covering and protection of a portion of the steel surface 011-13].

The erosion is considered as a purely mechanical phenomenon, in which the metal is removed or mechanically destroyed, so rendering physical changes. This mechanical removal process can be caused by both the presence of solid particles in the fluid (slurry erosion) 014,15] and by the presence of bubbles (erosion-cavitation) [16]. The erosion-cavitation-corrosion is considered as a tribochemical phenomenon.

Liang 0 investigated the impact of flow rate on corrosion of cast iron in re-mineralized desalinated seawater. The corrosion rate was found to increase from 4.72 to 9.17 mpy when Re number increased from 2 to 40. At slightly higher flow rates, however, the corrosion products form a protective layer at the steel surface and the metal loss is significantly reduced 0 . Additionally, the water may remove the protective scale as the flow rate continues to increase 0

As a result of the proper erosion and/or cavitation, the surface is almost free from possible corrosion products due to the bombardment of the particles within the fluid (solid particles in a liquid, liquid droplets in a gas, solid particles in a gas) on the solid surface, as a result of extremely high speeds of the fluid flow $(>10 \mathrm{~m} / \mathrm{s}$ ). All types of equipment that are exposed to fluids in motion are subjected to erosion-cavitationcorrosion [20,21]. The control and management of the erosion-corrosion synergism are required for operational safety and the reduction of production costs.

\section{MATERIALS AND METHODS}

The electrochemical cell, Figure 1, was developed and tested by NUP-ER/UFRN to investigate ferrous materials used in pipelines and analogous mechanical structural parts that are exposed to aqueous saline solutions in the presence of petroleum and gas. It was included $2.5 \% \mathrm{SiO}_{2}$ in the aqueous solution trapped in this cell during some tests to analyze detectable changes in the fluid flow concerning to its erosive mechanism and tribochemical action as wear rate inhibitor or activator. The physical dimensions of these particles ranging from 100 to $500 \mu \mathrm{m}$ in size. The method performed to measure the particle size was granulometry by laser scattering. The dispersant medium used in the analysis was distilled water. Equipment Microtrac model S3500.

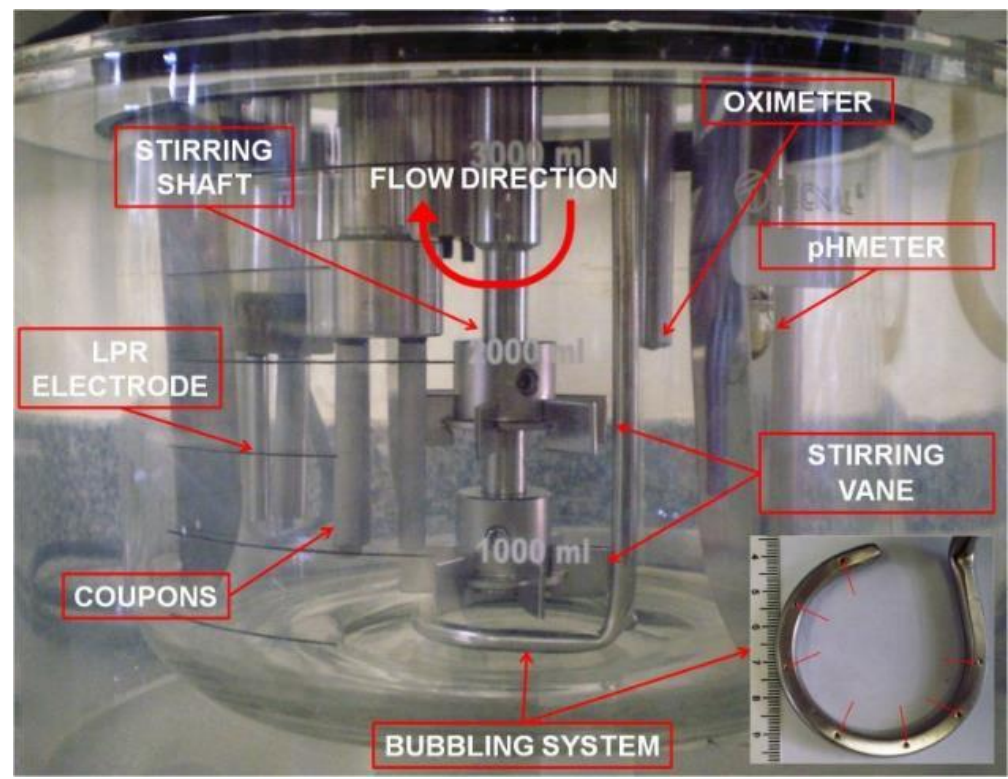

Figure 1: Electrochemical Cell equipped with $\mathrm{C}_{2}$ bubbling system (detail at right), a stirring for the saline solution, a linear polarization resistance (LPR) electrodes, specimens, oximeter and $\mathrm{pHmeter}$. 
A total of 84 cylindrical specimens were manufactured using AISI 1018 steel (Table 1) in accordance with the NACE RP 0775 Standard (1999), Figure 2(a). The test consists of immersion for 24 hours in saline solution with $10,000 \mathrm{ppm}$ of chlorides and at two temperatures by testing, $30^{\circ} \mathrm{C}$ or $70^{\circ} \mathrm{C}$, respectively. The test rig was set in two different conditions: unstirring and stirring $(5.0 \mathrm{~m} / \mathrm{s})$ saline solution, in order to provoke a forced turbulent flow. Additionally, $\mathrm{CO}_{2}$ gas injection $(5.0 \mathrm{~L} / \mathrm{min})$ was also employed to add some of the different environmental combinations. The overall methodology, the cell and each experimental step of this work was carried out according to Nunes da Silva 0.

Table 1: Chemical composition (\% mass) of AISI 1018 steel (specimens).

\begin{tabular}{llllllllll}
\hline $\mathbf{C}$ & $\mathbf{C u}$ & $\mathbf{C r}$ & $\mathbf{S}$ & $\mathbf{P}$ & $\mathbf{M n}$ & Mo & $\mathbf{N i}$ & $\mathrm{Si}$ & $\mathbf{F e}$ \\
\hline 0.18 & - & - & 0.05 & 0.04 & 0.85 & - & - & - & 98.88 \\
\hline
\end{tabular}

Visual Inspection, periodic (Rsm and Wsm) and stochastic parameters of the surface roughness (Ra, $\mathrm{Rq}$ and $\mathrm{Rz}$ ) and waviness (Wa, Wq and $\mathrm{Wz}$ ), respectively, were evaluated in a pair of diametrically opposite $\left(0^{\circ}\right.$ and $180^{\circ}$, Figure $\left.2(\mathrm{c})\right)$ generatrices of each cylindrical specimen. A set of three cylindrical zones A, B, C, Figure 2(b), was stratified conceptually. They can be visualized as a function of the surface response to the multiphase flow pressure field, temperature and ionic concentration fluctuations. These scenarios concern to the influence of the stirring or unstirring flow distributed in the upstream and downstream zones of the flow around each zone of the tested specimens. The Multitrend software V3.09® (CorrOcean ASA) monitors the rate of corrosion as a function of time.

The profilometry and microhardness (the subscribed numbers identify the loads used during the measurements; $0.05,0.1$ and $0.2 \mathrm{~N}$ respectively) resulting of the machining process of specimens are presented in Table 2, for further information see 0 .

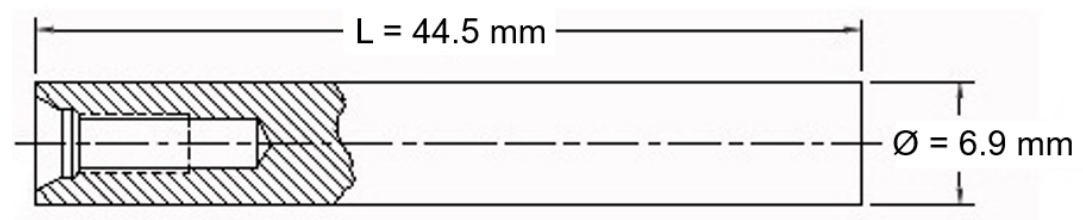

(a)

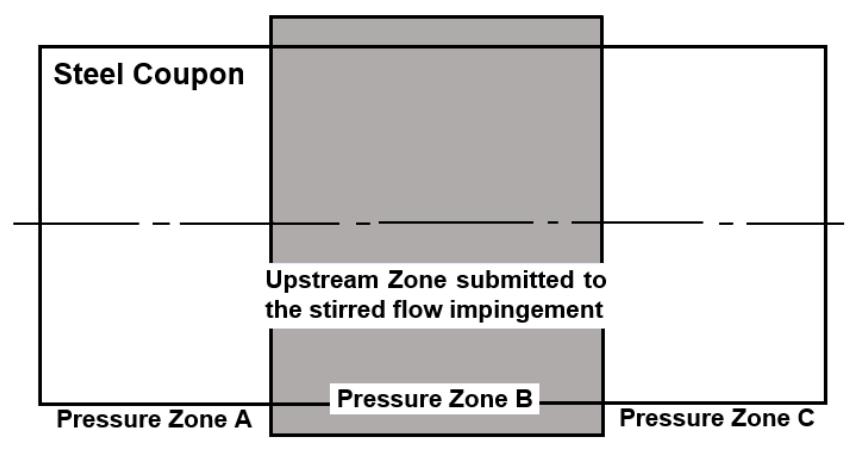

(b)

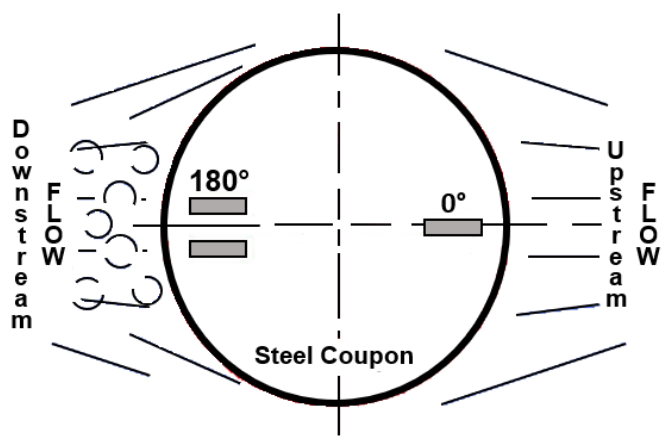

(c)

Figure 2: (a) Dimensions of the cylindrical specimen for testing; (b) Side view of the specimen and the three main flow pressure zones; (c) Top view of specimen and the two main generatrices at $0^{\circ}$ (upstream) and $180^{\circ}$ (downstream).

Table 2: Specimen characterization "as acquired".

\begin{tabular}{lccc}
\hline $\mathbf{H V}_{\mathbf{0 . 0 5}}$ & $190-263$ & $220-275$ & $195-290$ \\
\hline $\mathbf{H V}_{\mathbf{0 . 1 0}}$ & $230-280$ & $230-280$ & $245-310$ \\
\hline $\mathbf{H V}_{0.20}$ & $235-270$ & $230-290$ & $240-290$ \\
\cline { 1 - 4 } $\mathbf{R s m}(\boldsymbol{\mu m})$ & $35-42$ & $30-43$ & $35-44$ \\
\hline $\mathbf{R a}(\boldsymbol{\mu m})$ & $0.23-0.27$ & $0.19-0.23$ & $0.23-0.34$ \\
\hline
\end{tabular}




\begin{tabular}{lccc}
\hline $\mathbf{R q}(\mu \mathrm{m})$ & $0.29-0.35$ & $0.25-0.30$ & $0.31-0.45$ \\
\hline $\mathbf{R z}(\boldsymbol{\mu m})$ & $1.6-2.5$ & $1.3-2.1$ & $1.9-2.5$ \\
\hline & $\mathbf{A}$ & $\mathbf{B}$ & $\mathbf{C}$ \\
\hline $\mathbf{R z}(\boldsymbol{\mu m})$ & $2.1-2.6$ & $1.9-2.3$ & $1.8-3.0$ \\
\hline $\mathbf{R q}(\boldsymbol{\mu m})$ & $0.33-0.40$ & $0.33-0.37$ & $0.35-0.49$ \\
\hline $\mathbf{R a}(\boldsymbol{\mu m})$ & $0.25-0.32$ & $0.26-0.29$ & $0.26-0.37$ \\
\hline $\mathbf{R s m}(\boldsymbol{\mu m})$ & $40-46$ & $39-54$ & $36-70$ \\
\hline $\mathbf{H V}_{\mathbf{0 . 2 0}}$ & $240-295$ & $220-300$ & $215-255$ \\
\hline $\mathbf{H V}_{\mathbf{0 . 1 0}}$ & $220-305$ & $255-290$ & $220-270$ \\
\hline $\mathbf{H V}_{\mathbf{0 . 0 5}}$ & $240-295$ & $215-270$ & $240-270$ \\
\hline & & & \\
\hline
\end{tabular}

A software was used for the statistical comparison among sets of data at $95 \%$ confidence level. The Fisher LSD test was chosen because it is possible to make the statistical comparison between groups of sample data of the same variable. The analysis results in the assertion that the groups are similar to or different from that pre-defined reliability level.

\section{RESULTS AND DISCUSSION}

The statistical analysis of the tests results was carried out in order to identify if the different zones had a significant difference between the roughness data ( $\mathrm{Ra}, \mathrm{Rq}, \mathrm{Rz}, \mathrm{Rsm}$ ) and surface roughness (Wa, Wq, Wz, Wsm) between them and/or different generatrices.

The specimens were analyzed at five different conditions: Specimen as acquired, tested without fluid mechanical stirring at $30^{\circ} \mathrm{C}$ (SAM30), tested without fluid mechanical stirring at $70^{\circ} \mathrm{C}$ (SAM70), tested with fluid mechanical stirring at $70^{\circ} \mathrm{C}$ (DC70), tested with fluid mechanical stirring and $\mathrm{SiO}_{2}$ particles at $70^{\circ} \mathrm{C}$ (DEC70). The result of this analysis is presented in Table 3.

Table 3: Parameters that presented significant difference in the statistical analysis of the roughness and surface corrugation of the steel specimens.

\begin{tabular}{|c|c|c|c|c|c|c|c|c|}
\hline \multirow{2}{*}{ CONDITION } & \multicolumn{8}{|c|}{ PARAMETERS - PRESENTED SIGNIFICANT DIFFERENCE STATISTICALLY } \\
\hline & $\mathbf{R a}$ & $\mathbf{R q}$ & $\mathbf{R z}$ & Rsm & Wa & Wq & Wz & Wsm \\
\hline as acquired & $\mathrm{X}$ & $\mathrm{X}$ & & & $\mathrm{X}$ & $\mathrm{X}$ & $\mathrm{X}$ & \\
\hline SAM30 & $\mathrm{X}$ & $\mathrm{X}$ & *X & $\mathrm{X}$ & & & $\mathrm{X}$ & $\mathrm{X}$ \\
\hline SAM70 & $\mathrm{X}$ & $\mathrm{X}$ & $\mathrm{X}$ & $\mathrm{X}$ & & & & \\
\hline DC70 & $\mathrm{X}$ & ${ }^{* * *} \mathrm{X}$ & & $X$ & & & & \\
\hline DEC70 & $X$ & $\mathrm{X}$ & $X$ & $X$ & $X$ & $\mathrm{X}$ & $X$ & $X$ \\
\hline
\end{tabular}

\subsection{Specimen as acquired}

A profilometric analysis between the zones A, B and C in their upstream and downstream generatrices of the specimen in the condition "as acquired" showed that there was a difference in some parameters of the surface roughness and waviness revealing heterogeneity due to the manufacturing process (Figure 3).
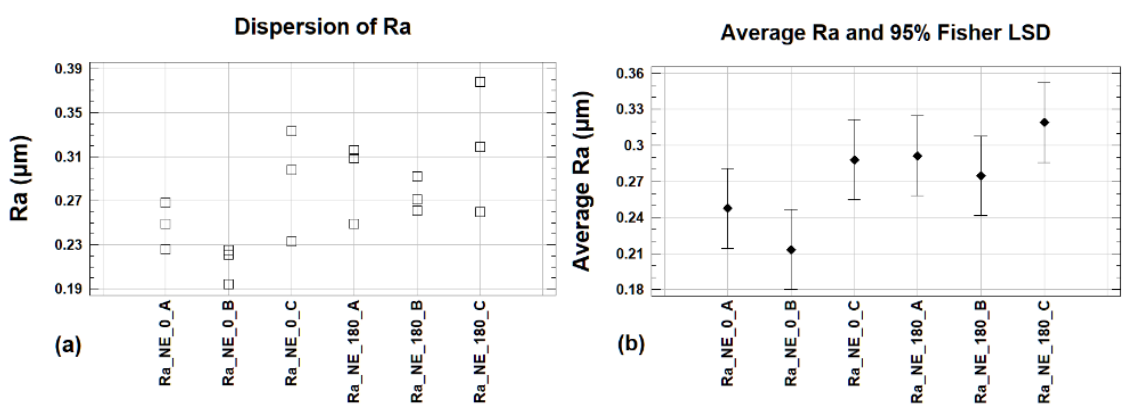
2)

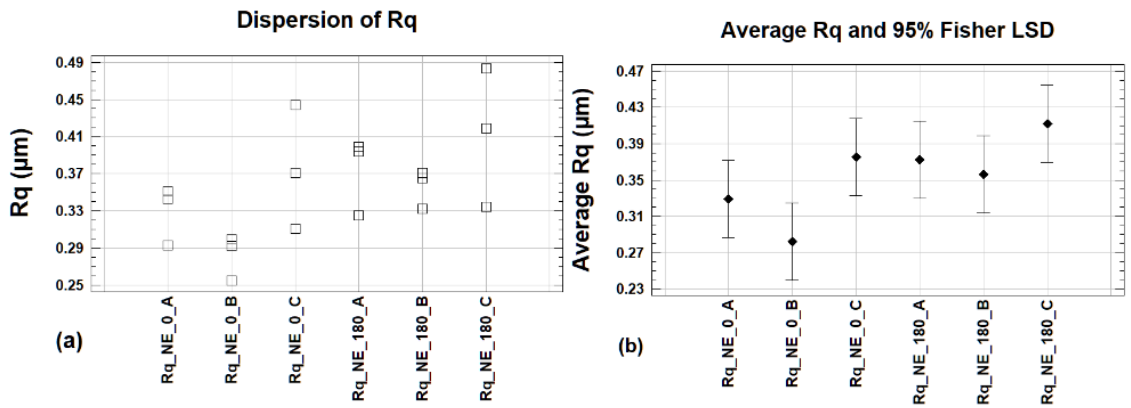

Figure 3: Specimen as acquired, results of $\mathrm{Ra}$ and $\mathrm{Rq}$ in the $\mathrm{A}, \mathrm{B}, \mathrm{C}$ generatrix zones: 1.a) Ra dispersion; 1.b) Ra average; 2. a) $\mathrm{Rq}$ dispersion; $2 . \mathrm{b}) \mathrm{Rq}$ average.

The dispersion of waviness values in some regions showed higher values than the others (Figure 4).

1)
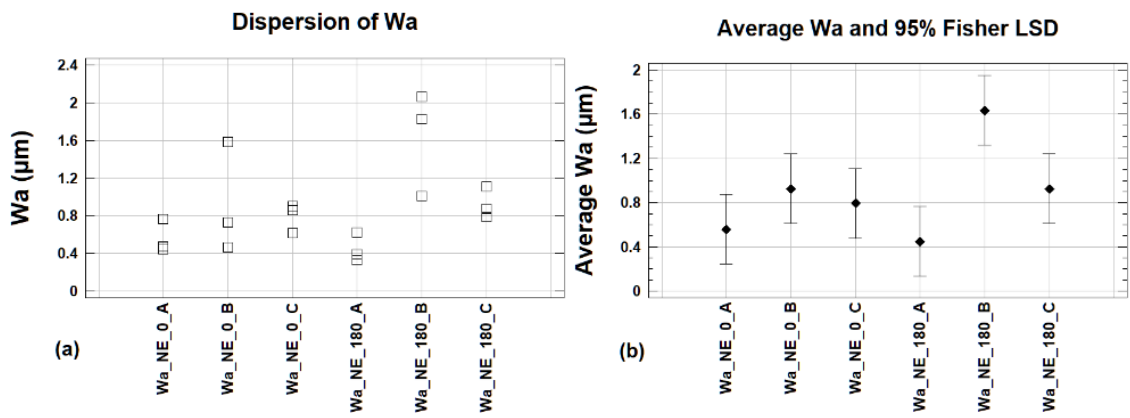

2)
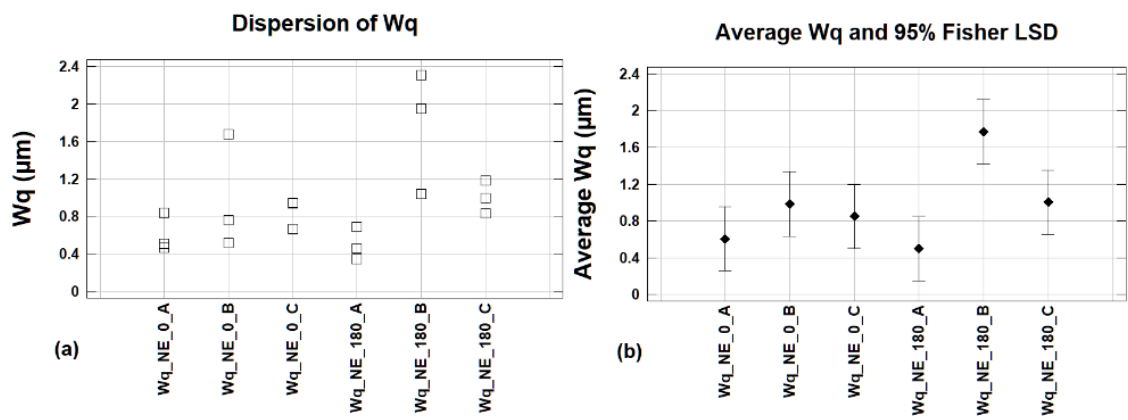

3)
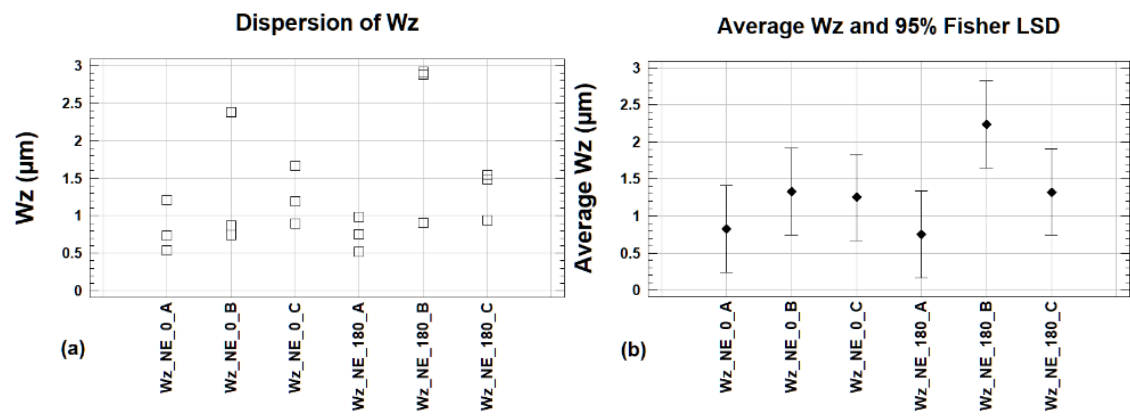

Figure 4: Specimen as acquired, results of $\mathrm{Wa}, \mathrm{Wq}$ and $\mathrm{Wz}$ in the A, B, C generatrix zones: 1.a) Wa dispersion; 1.b) Wa average; 2.a) Wq dispersion; 2.b) Wq average; 3.a) Wz dispersion; 3.b) Wz average.

\subsection{Test without fluid mechanical stirring at $30^{\circ} \mathrm{C}$ (SAM30)}

From the results, it was observed that the dispersion values were higher for parameters $\mathrm{Ra}, \mathrm{Rq}, \mathrm{Rz}$ and $\mathrm{Rsm}$ 
by the Fisher statistical analysis (Figure 5).

1)
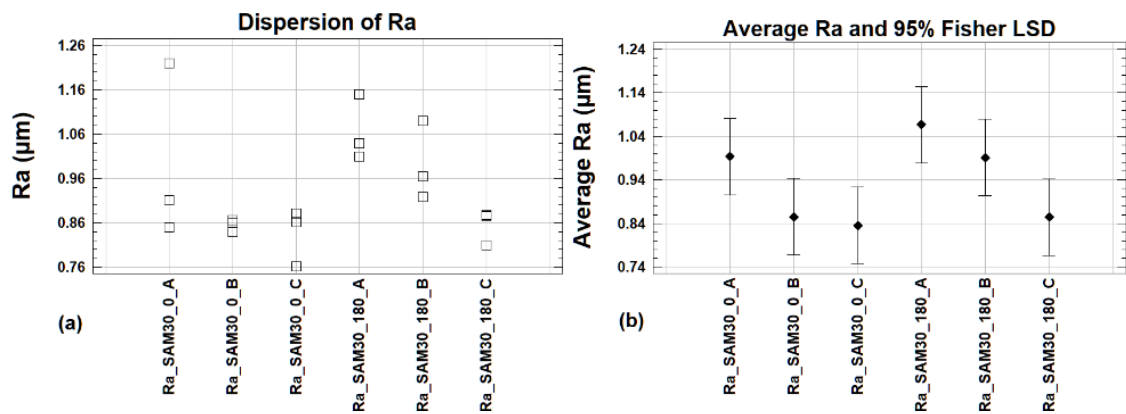

2)
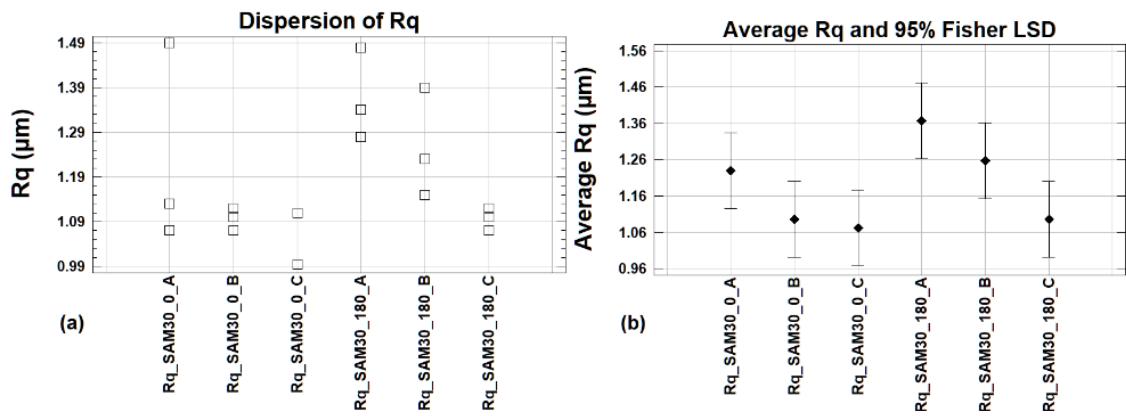

3)
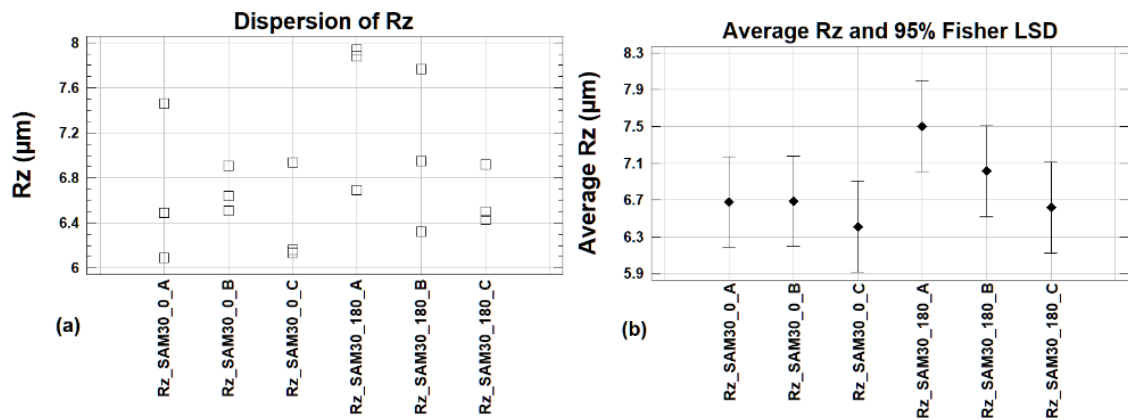

4)
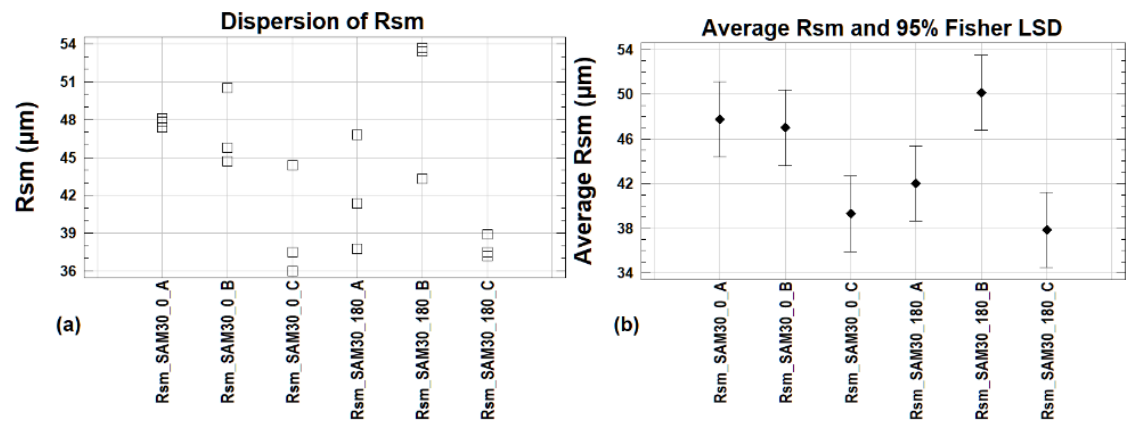

Figure 5: Specimen tested at $30^{\circ} \mathrm{C}$ without stirring, results of $\mathrm{Ra}, \mathrm{Rq}, \mathrm{Rz}$ and $\mathrm{Rsm}$ in the $\mathrm{A}, \mathrm{B}, \mathrm{C}$ generatrix zones: 1.a) Ra dispersion; 1.b) Ra average; 2.a) Rq dispersion; 2.b) Rq average; 3.a) Rz dispersion; 3.b) Rz average; 4.a) Rsm dispersion; 4.b) Rsm average.

It was observed that there was a higher dispersion in the values obtained for the waviness parameters $\mathrm{Wz}$ and Wsm (Figure 6) by the Fisher statistical analysis. 
1)

2)

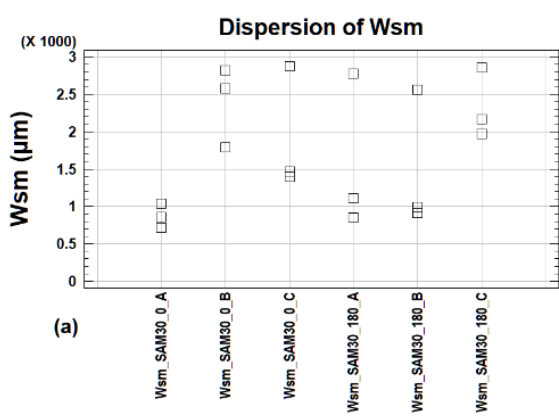

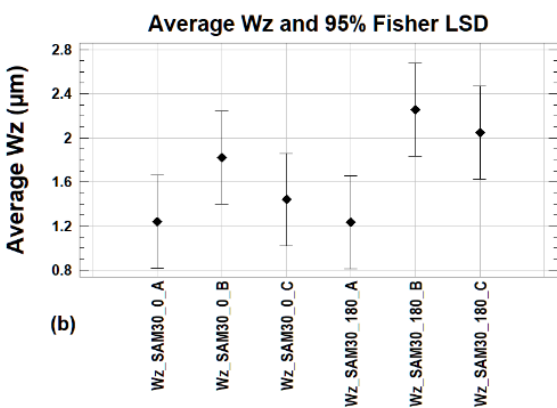

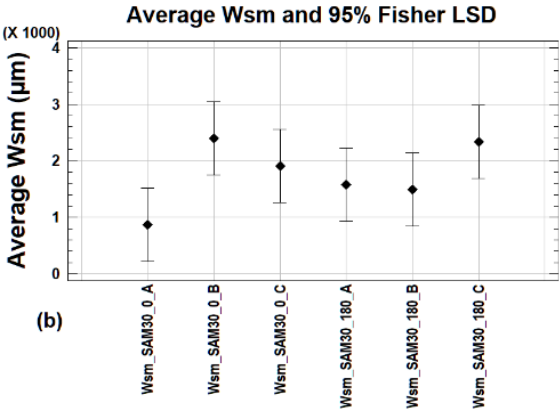

Figure 6: Specimen tested at $30^{\circ} \mathrm{C}$ without stirring, results of $\mathrm{Wz}$ and $\mathrm{Wsm}$ in the $\mathrm{A}, \mathrm{B}, \mathrm{C}$ generatrix zones: 1.a) Wz dispersion; 1.b) Wz average; 2.a) Wsm dispersion; 2.b) Wsm average.

The results (Figures 5 and 6) demonstrated that, in spite of the absence of a fluid in motion, the surface showed a certain degree of heterogeneity, as confirmed by means of statistical differences.

The Figure 7 presents the generatrices upstream $\left(0^{\circ}\right)$ and downstream $\left(180^{\circ}\right)$ of one specimen after testing during 24 hours without mechanical stirring and gas injection at $30^{\circ} \mathrm{C}$. The corrosive wear mechanism, under this condition, was influenced by some factors such as the physico-chemical reactions of iron corrosion (Equations 1 and 2), concentration of the chemicals and temperature.

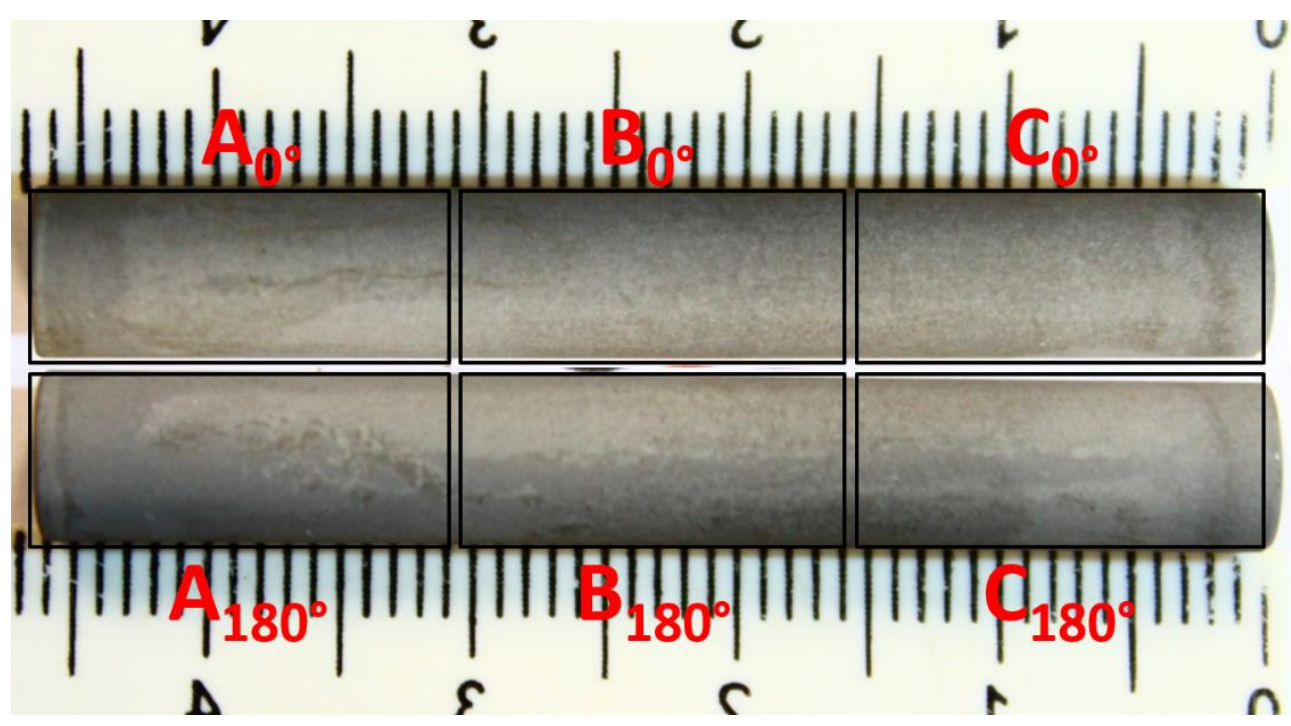

Figure 7: Zones A, B and $\mathrm{C}$ of a specimen after testing at $30^{\circ} \mathrm{C}$ without stirring in the saline bath. 
3.3 Test without fluid mechanical stirring at $70^{\circ} \mathrm{C}$ (SAM70)

Figure 8 includes the results of surface roughness, as well as the respective dispersion of the measured values. They were computed for the test without mechanical stirring and gas injection at $70^{\circ} \mathrm{C}$. Statistical differences between the zones $\mathrm{A}, \mathrm{B}$ and $\mathrm{C}$ as well as between the generatrices, $0^{\circ}$ and $180^{\circ}$, for the parameters $\mathrm{Ra}, \mathrm{Rq}$, $\mathrm{Rz}$ and Rsm are also presented. These results probably were influenced by the convective flow lines present in the heated multiphasic fluid into the cell 0 .

1)
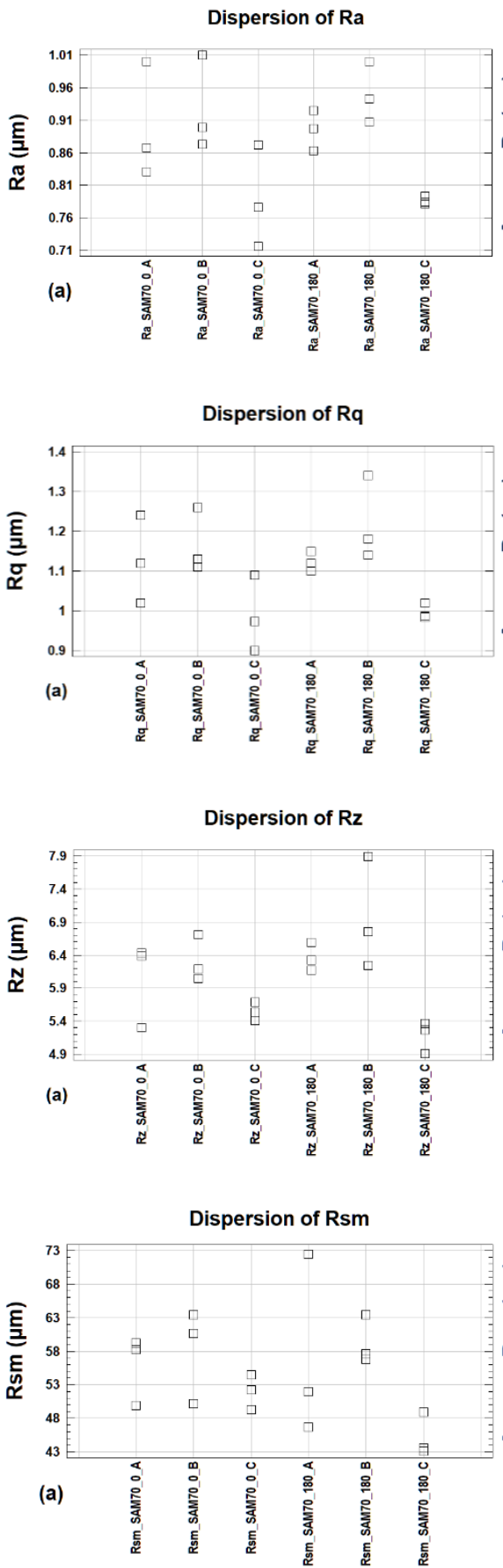
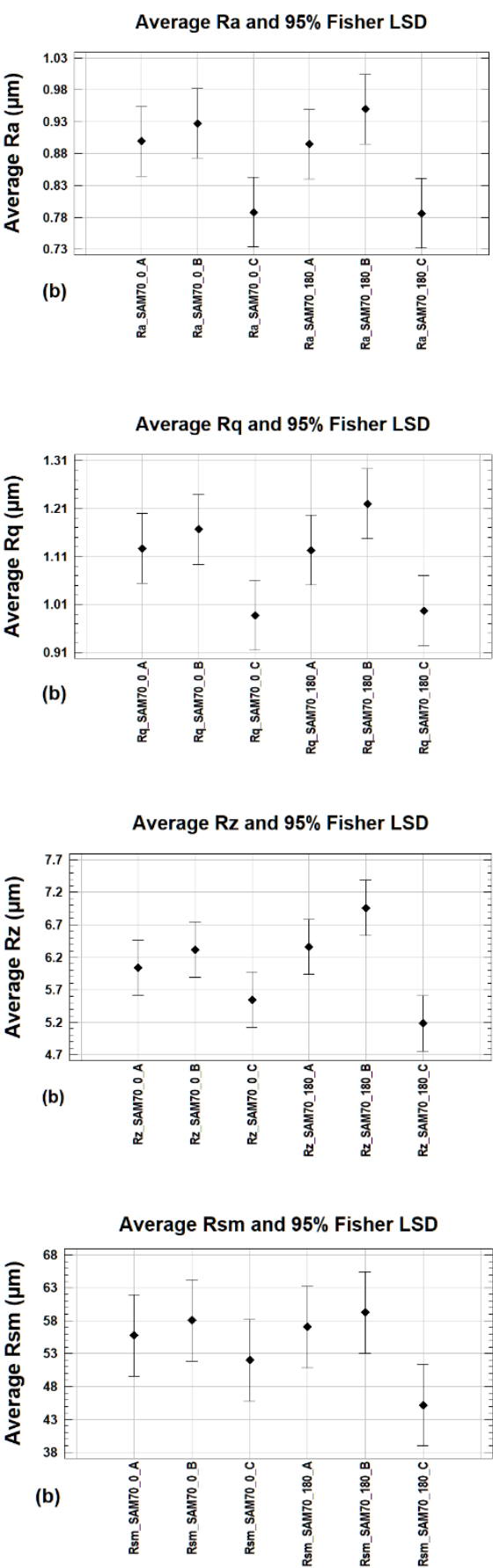

Figure 8: Specimen tested at $70^{\circ} \mathrm{C}$ without stirring, results of $\mathrm{Ra}, \mathrm{Rq}, \mathrm{Rz}$ and $\mathrm{Rsm}$ in the $\mathrm{A}, \mathrm{B}, \mathrm{C}$ generatrix zones: 1.a) Ra dispersion; 1.b) Ra average; 2.a) Rq dispersion; 2.b) Rq average; 3.a) Rz dispersion; 3.b) Rz average; 4.a) Rsm dispersion; 4.b) Rsm average.

There is a certain degree of homogeneity in superficial waviness of the specimen after the test in the condition SAM70.

The Figure 9 shows the generatrices upstream $\left(0^{\circ}\right)$ and downstream $\left(180^{\circ}\right)$ of one of the specimens 
after 24 hours test at $70^{\circ} \mathrm{C}$, without mechanical stirring and gas injection. As in the condition SAM30, the corrosive wear mechanism, in this condition, may have been influenced by factors such as the physicochemical reactions of iron corrosion, concentration of chemicals besides the convection currents caused by heating.

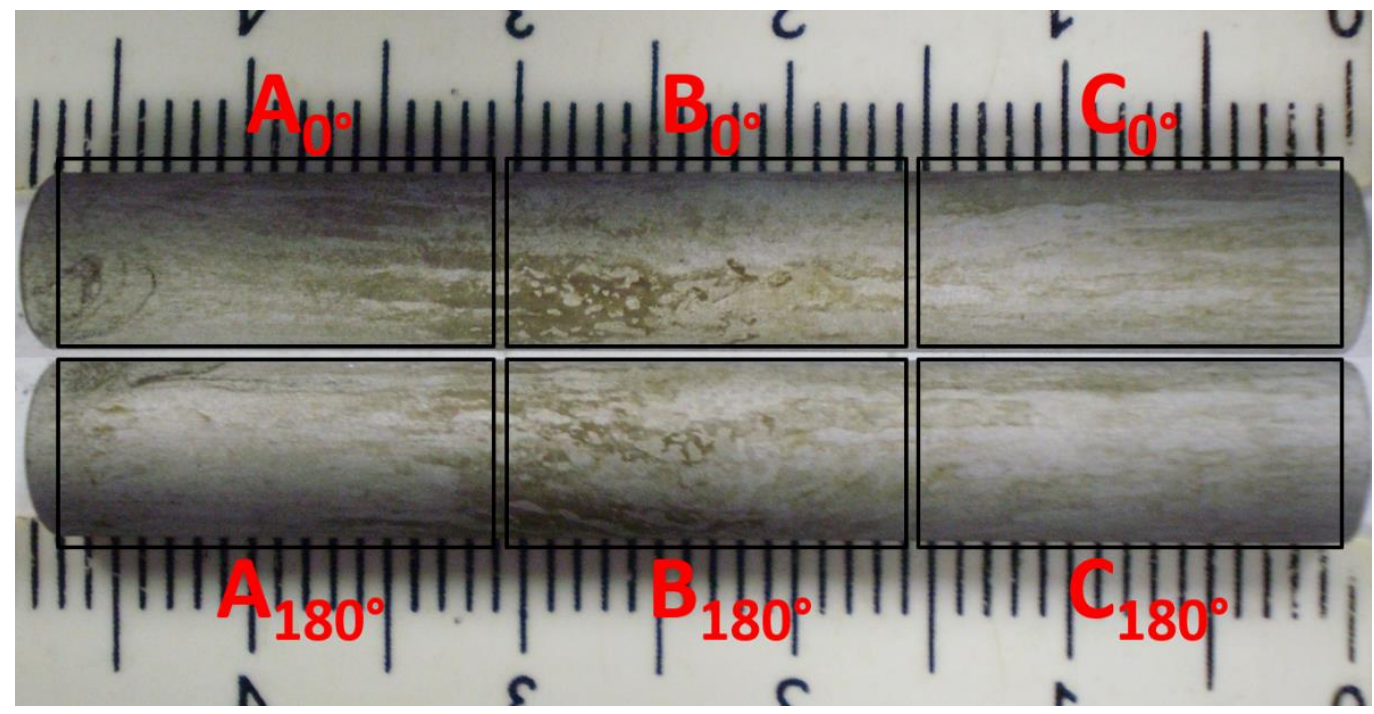

Figure 9: Zones A, B and $\mathrm{C}$ of a specimen after testing at $70^{\circ} \mathrm{C}$ without stirring in the saline bath.

\subsection{Test with fluid mechanical stirring at $70^{\circ} \mathrm{C}$ (DC70)}

The parameters of surface roughness $\mathrm{Ra}, \mathrm{Rq}$ and $\mathrm{Rsm}$ showed statistic differences in the comparison between zones. However, in the comparison between generatrices, only Ra and Rsm had differences (Figure 10) for the condition of corrosive-cavitative wear at $70^{\circ} \mathrm{C}$. These results confirm the hypothesis that the mechanisms that acts in the upstream generatrix differ from that of downstream of specimen.
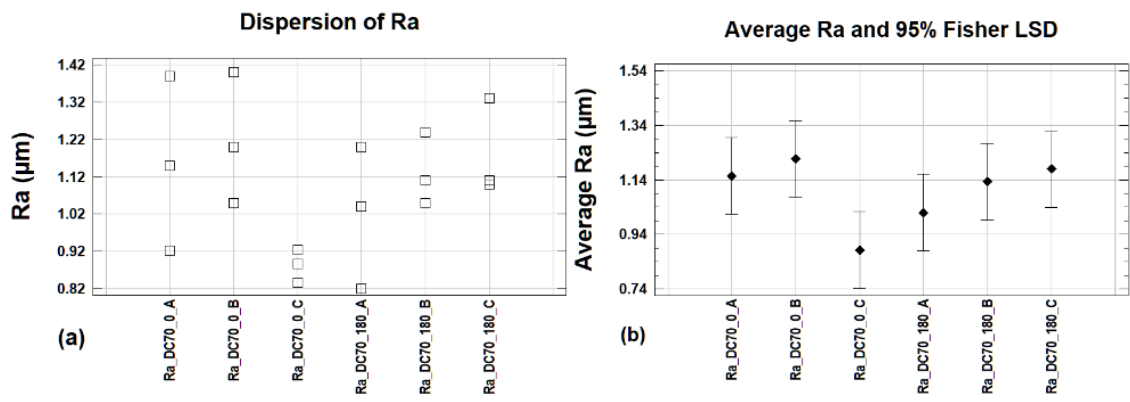

2)
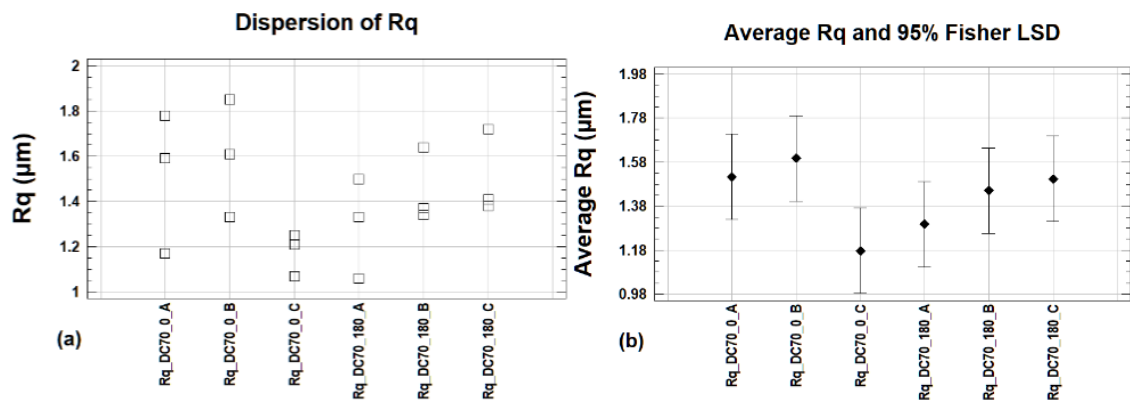

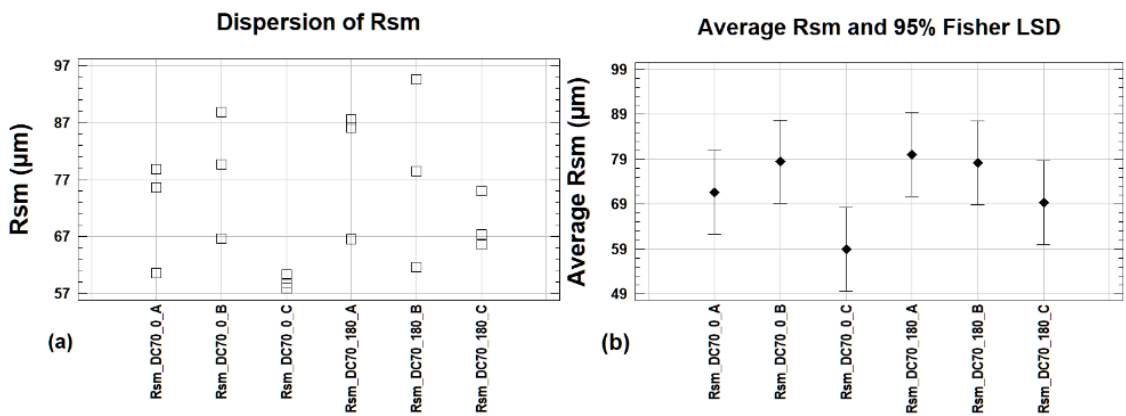

Figure 10: Specimen tested at $70^{\circ} \mathrm{C}$ with stirring, results of $\mathrm{Ra}, \mathrm{Rq}$ and $\mathrm{Rsm}$ in the $\mathrm{A}, \mathrm{B}, \mathrm{C}$ generatrix zones: 1.a) $\mathrm{Ra}$ dispersion; 1.b) Ra average; 2.a) Rq dispersion; 2.b) Rq average; 3.a) Rsm dispersion; 3.b) Rsm average.

There is a certain degree of homogeneity in surface waviness of specimen after the test under the condition DC70.

The Figure 11 shows the upstream $\left(0^{\circ}\right)$ and downstream $\left(180^{\circ}\right)$ generatrices of one specimen after testing during 24 hours under corrosive-cavitative wear condition at $70^{\circ} \mathrm{C}$. Under this condition, thermal and chemical reaction rates, besides the concentration of chemicals and multiphasic fluid hydrodynamics participated significantly on the synergic mechanism of corrosive-cavitative wear. The upstream generatrix has the influence of a laminar Couette flow, while the downstream generatrix has a strong influence on the formation of Taylor vortices associated to the stirring flow condition and also the presence of $\mathrm{CO}_{2}$ bubbles.

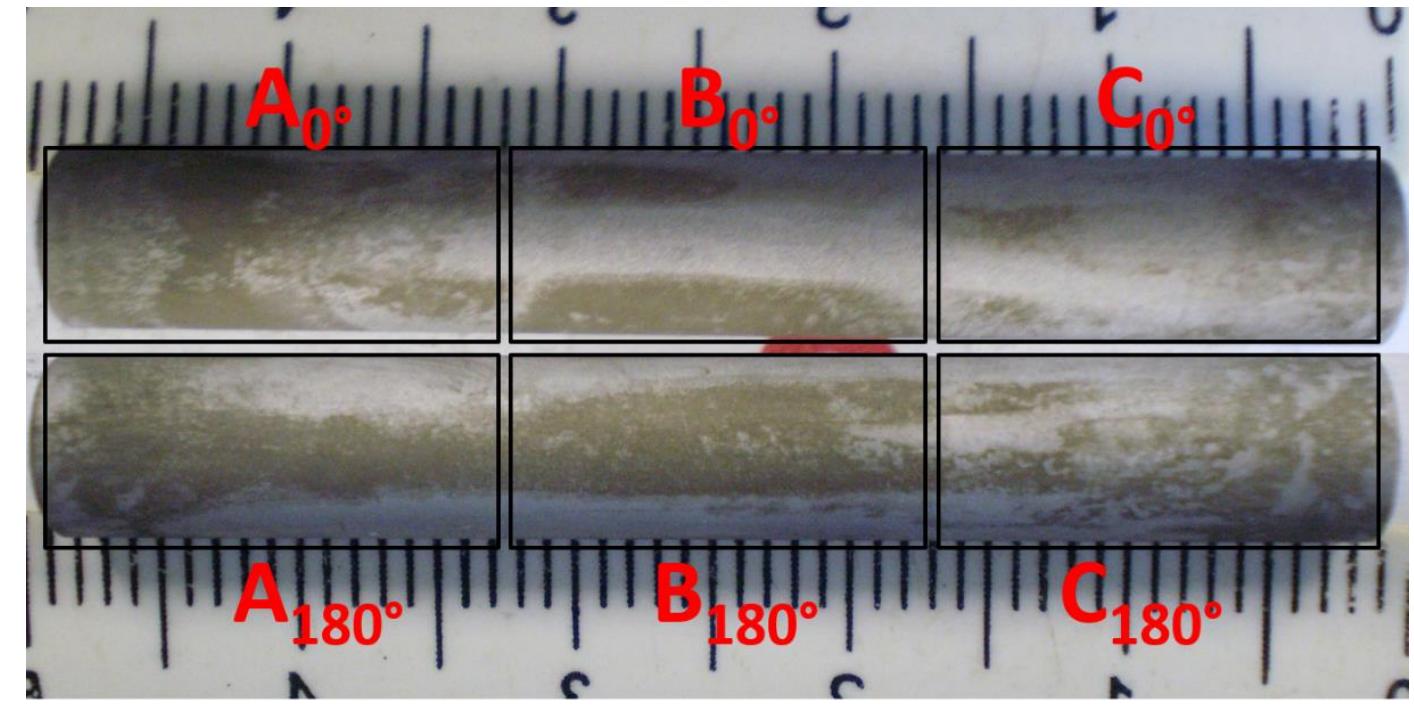

Figure 11. Zones A, B and $\mathrm{C}$ of a specimen after testing at $70^{\circ} \mathrm{C}$ with stirring in the saline bath.

\subsection{Test with fluid mechanical stirring and $\mathrm{SiO}_{2}$ particles at $70^{\circ} \mathrm{C}$ (DEC70)}

Figure 12 contains graphs of the surface roughness parameters, $\mathrm{Ra}, \mathrm{Rq}, \mathrm{Rz}$ and Rsm, respectively, on the condition of erosive-corrosive wear at $70^{\circ} \mathrm{C}$. They showed significant statistic differences between the upstream and downstream generatrices of the specimen, as well as higher dispersion in some zones.

The surface roughness increased the location of the crack in passivated films, improves the level of the local turbulence promoting the separation of the passivated films and removing the metalic surface, i.e., this mechanism may occur in regions with formation of Taylor vortices (downstream) 0 . 
1)

2)

3)

4)
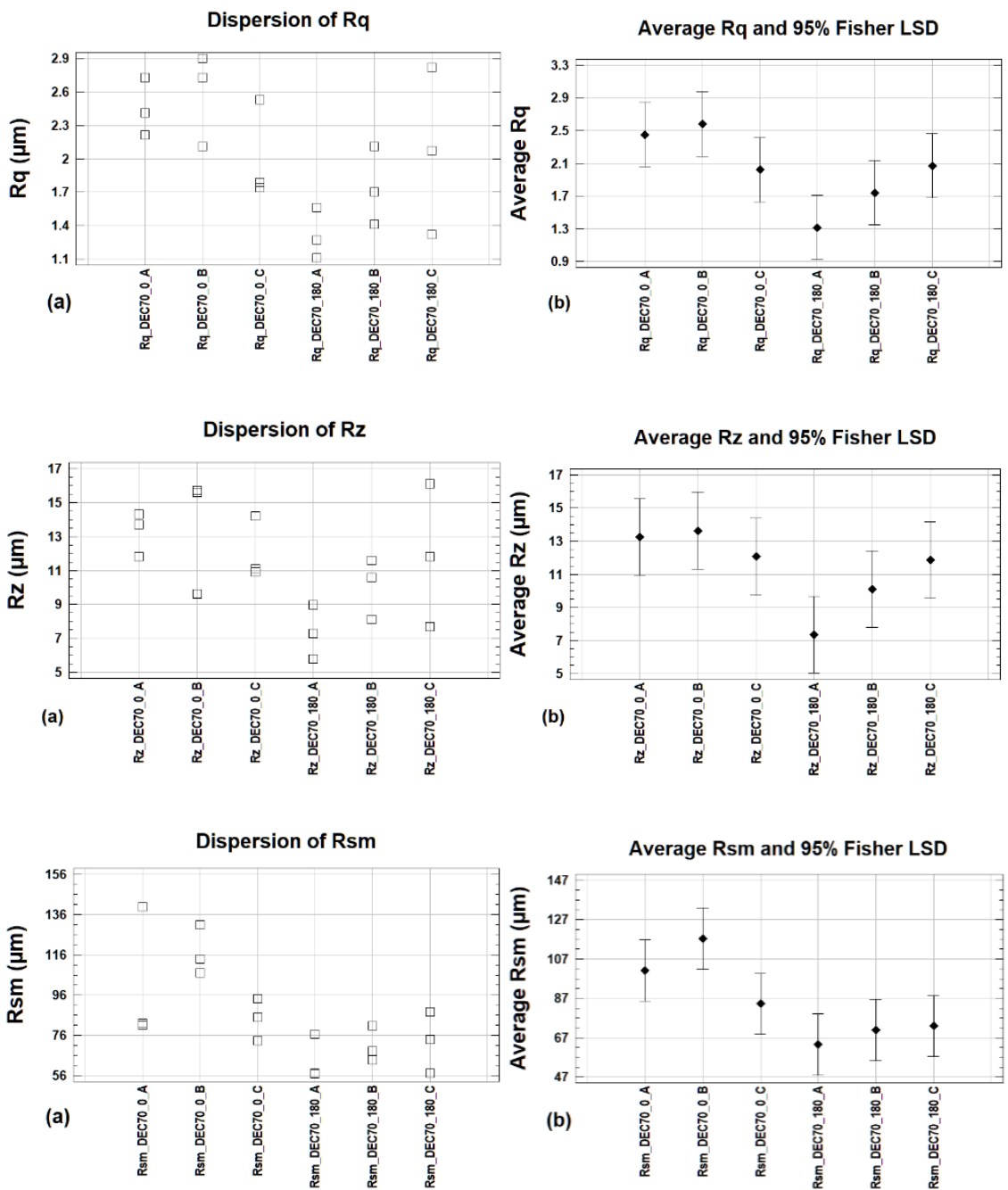

Figure 12: Specimen tested at $70^{\circ} \mathrm{C}$ with stirring and $\mathrm{SiO}_{2}$ particles in the saline bath, results of $\mathrm{Ra}$ in the $\mathrm{A}, \mathrm{B}, \mathrm{C}$ generatrix zones: 1.a) Ra dispersion; 1.b) Ra average; 2.a) Rq dispersion; 2.b) Rq average; 3.a) Rz dispersion; 3.b) Rz average; 4.a) Rsm dispersion; 4.b) Rsm average.

The statistical analysis for roughness parameters also confirm that the active damage mechanisms in the diametrically opposite generatrices differ due to (1) upstream jet impingement and (2) the formation of bubbles associated with downstream vortices. The dispersions of the values obtained were lower in some areas for this test condition. 
1)
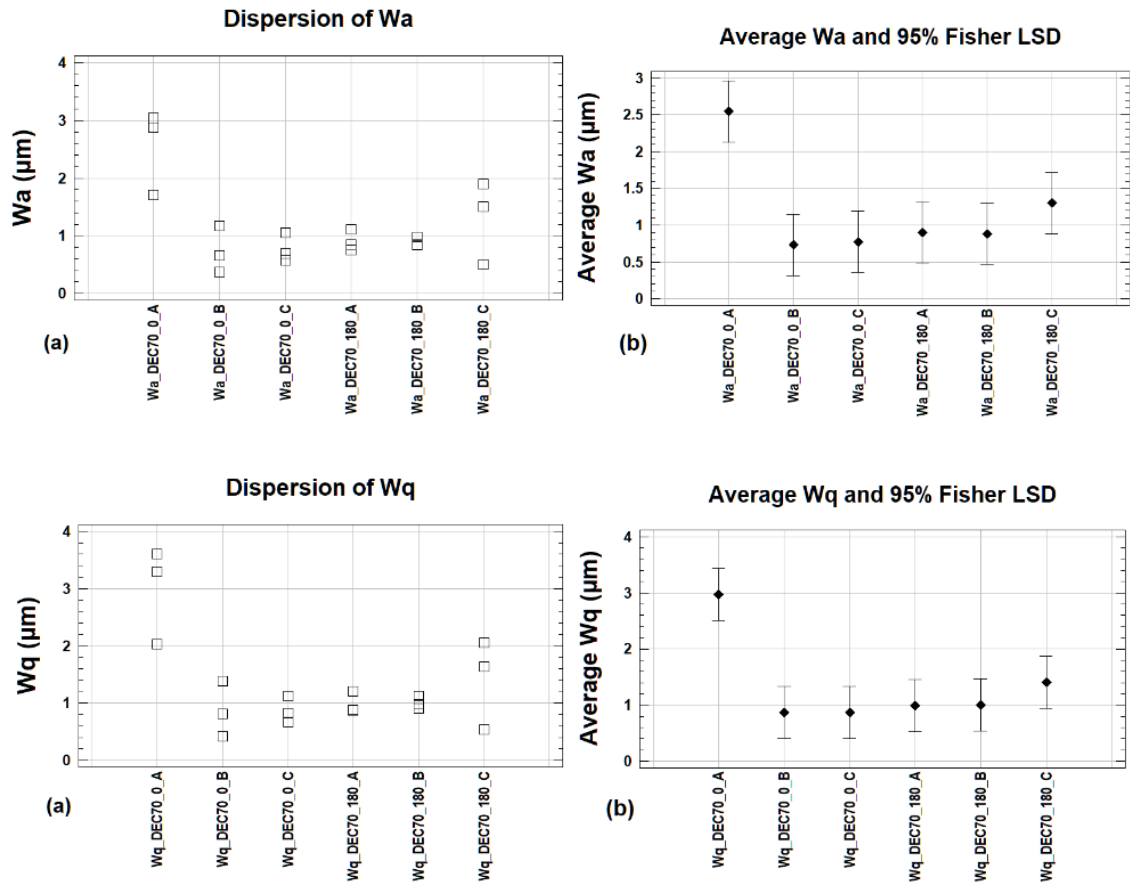

2)
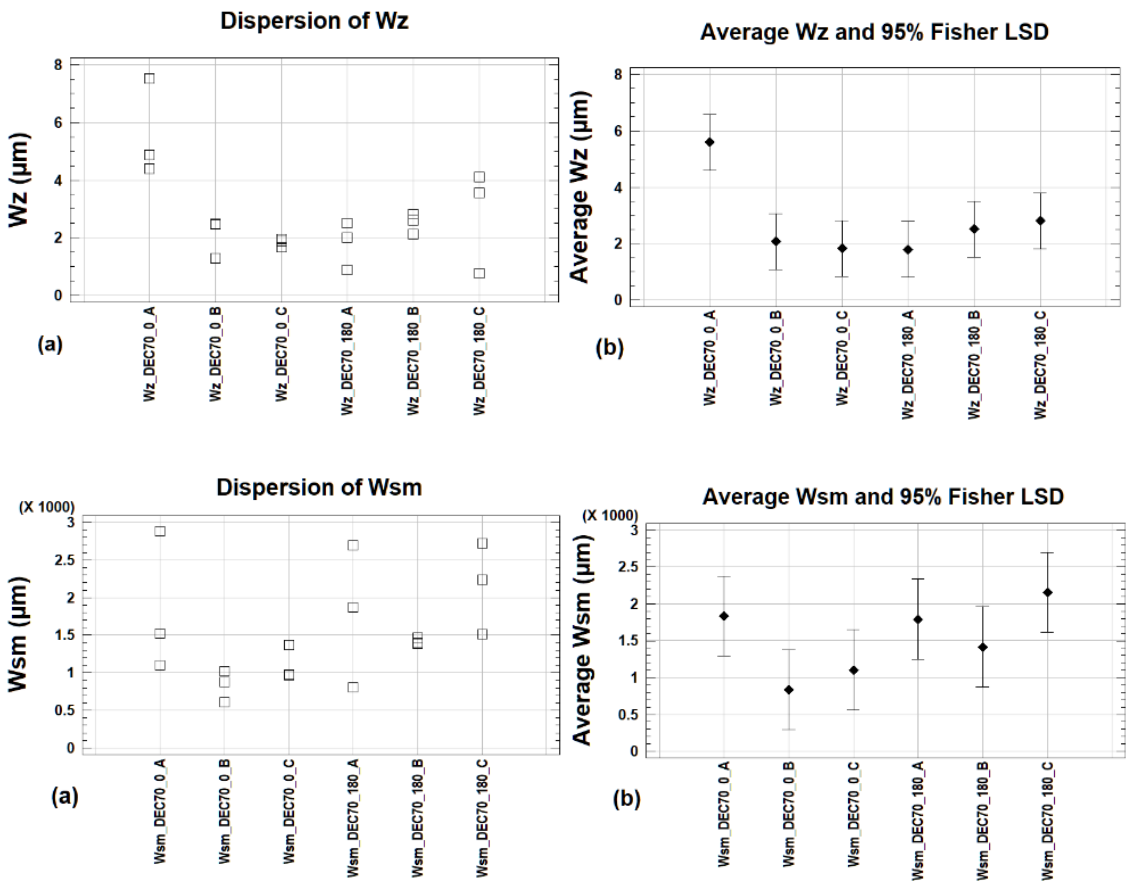

Figure 13: Specimen tested at $70^{\circ} \mathrm{C}$ with stirring and $\mathrm{SiO}_{2}$ particles in the saline bath, results of $\mathrm{Wa}$ in the $\mathrm{A}, \mathrm{B}, \mathrm{C}$ generatrix zones: 1.a) Wa dispersion; 1.b) Wa average; 2.a) Wq dispersion; 2.b) Wq average; 3.a) Wz dispersion; 3.b) Wz average; 4.a) Wsm dispersion; 4.b) Wsm average.

Figure 14 shows the generatrices of upstream $\left(0^{\circ}\right)$ and downstream $\left(180^{\circ}\right)$ in one of the specimens after 24 hours test under the condition of erosive-corrosive wear at $70^{\circ} \mathrm{C}$. For this condition, the upstream generatrix has the influence of the laminar Couette flow with a smaller Reynolds number. It is associated with the presence of silica constituting a slurry erosion. In the downstream generatrix, Taylor vortices also were influenced by particulate matter and $\mathrm{CO}_{2}$ bubbles dispersed in the flow, although the formation of these bubbles is more difficult due to smaller Reynolds numbers associated to the $\mathrm{SiO}_{2}$ particulates. 


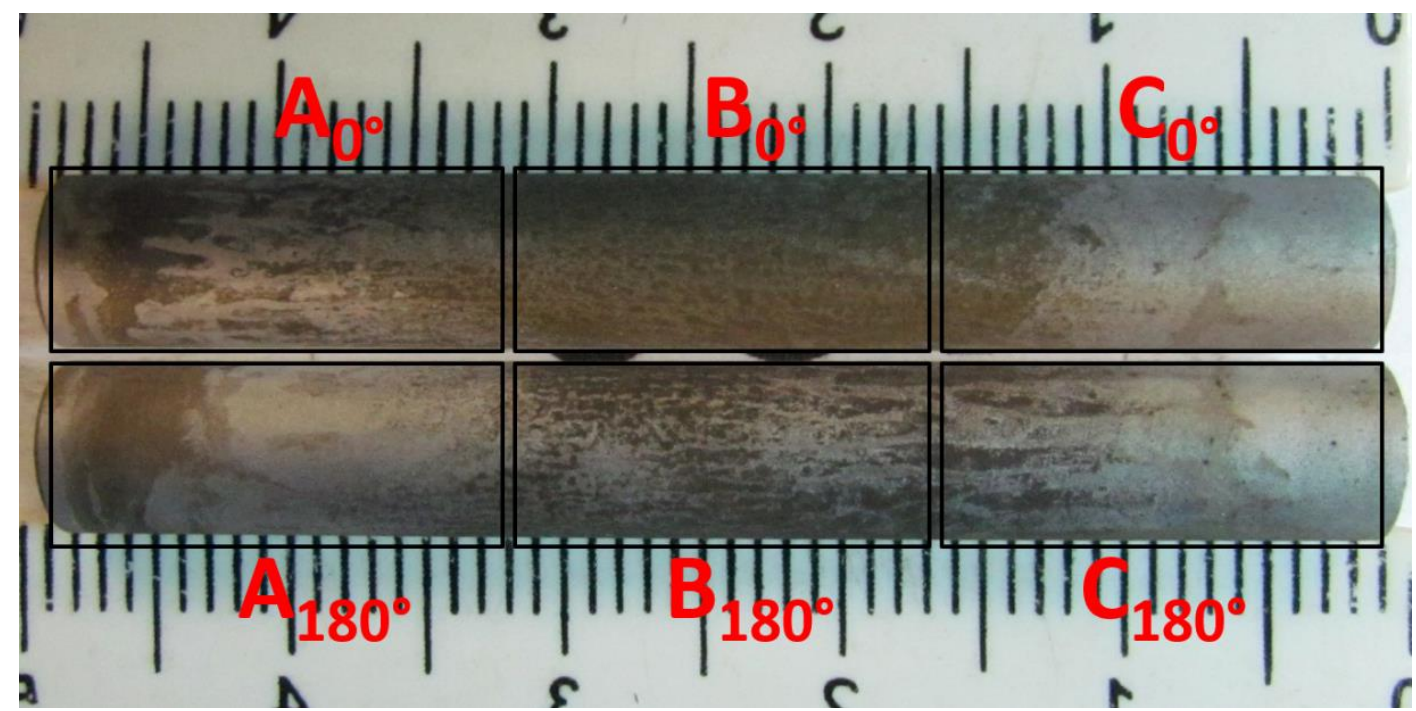

Figure 14: Zones A, B and $\mathrm{C}$ of a specimen after testing at $70^{\circ} \mathrm{C}$ with stirring and $\mathrm{SiO} 2$ particles in the saline bath.

\section{CONCLUSIONS}

The results of the Fisher statistical analysis at $95 \%$ confidence interval of the periodic and non-periodic parameters of the roughness and surface waviness of the middle and extremes zones of a same generatrix and the generatrices diametrically opposites of a cylindrical specimen, demonstrated some significant differences, consistent with the wear mechanism and morphology of the damages in these regions.

The surface waviness suffered a smaller alteration when compared to the surface roughness. Thus, the surface waviness cannot be the only parameter to identify the wear, because, although it has an easier identification, it may mask other data, as was the case of surface roughness for the present study, a factor that influences directly the shear stress of the fluid, and therefore, the damage to the material $[9,23,24]$

The hydrodynamics of the fluidic suspension around the specimen and the particulates present there in limited areas in each specimen suggest different mechanisms of wear, from the surface texture, microhardness [20] and from the analysis of the results from RPL, mass variation as published in a previous paper [22].

In both corrosive-cavitative wear tests, as in corrosive-erosive, the fluid flow within the cell showed traces of laminar Couette flow and presence of Taylor vortices being classified as turbulent boundary layer [9]. This evidence was characterized morphological and physically through visual inspection and by the response of the texture changes of the tested specimens, suggesting since a transition until a competition between erosive-cavitative wear and corrosion mechanisms.

\section{AKNOWLEDGMENTS}

The authors would like to express their thanks to: CNPq, the Brazilian National Council for Research for the financial support to one of the authors, Nunes da Silva, during his postgraduate studies carried out in the Post Graduate Program in Mechanical Engineering-PPGEM at the UFRN and to CENPES/PETROBRAS for the infrastructure investments at NUP-ER.

\section{BIBLIOGRAPHY}

[1] SILVA, F. N. Desgaste corrosivo-cavitativo- erosivo de um aço-carbono em meio aquoso com frações de sal $(\mathrm{NaCl}), \mathrm{CO}_{2}$ e particulados sólidos $\left(\mathrm{SiO}_{2}\right)$, Dissertation M.Sc., PPGEM/UFRN, Natal, Rio Grande do Norte, Brasil, 2012.

[2] KERMANI, M.B., MORSHED A., "Carbon dioxide corrosion in oil and gas production - a compendium”, Corrosion, v.59, pp. 659-683, 2003. 
[3] ABAYARATHANA D., NARAGHI A., "Evaluation of corrosion inhibitor for co2 corrosion using electrochemical and non-electrochemical techniques”, Corrosion, n. 1060, 2001.

[4] SHADLEY J.R., SHIRAZI S.A., DAYALAN E., et al., "Erosion-corrosion of a carbon steel elbow in a carbon dioxide environment", Corrosion, v. 52, n. 9, pp. 714-723, 1996.

[5] LINTER B.R., BURSTEIN G.T., "Reactions of pipeline steel in carbon dioxide solutions", Corrosion Science, v. 41, pp. 117-139, 1999.

[6] STACK M.M., "Mapping tribo-corrosion processes in dry and in aqueous conditions: some new directions for the new millennium", Tribology International, v. 35, pp. 681-689, 2002.

[7] MISHRA B., AL-HASSAN S., OLSON D. L., et al., "Development of a predictive model for activationcontrolled corrosion of steel in solutions containing carbon dioxide", Corrosion, v. 53, n. 11, pp. 852-859, 1997.

[8] MORA-MENDONZA J. L., TURGOOSE S., "Fe ${ }_{3} \mathrm{C}$ influence on the corrosion rate of mild steel in aqueous $\mathrm{CO}_{2}$ systems under turbulent flow conditions", Corrosion Science, n. 44, pp. 1223-1246, 2002.

[9] NESIC S., POSTLETHWAITE J., OLSEN S., “An electrochemical model for prediction of corrosion of mild steel in aqueous carbon dioxide solution”, Corrosion, v. 52, n. 4, pp. 280-294, 1996.

[10] FERREIRA, L.R.M., PONTE, H.A., SANCHES, L.S., et al., " $\mathrm{CO}_{2}$ corrosion in the regime between the static and turbulent flow regimes", Materials Research, v. 18, n. 2, pp. 245-249, 2015.

[11] HAN J., YOUNG D., NESIC S., "Characterization of the passive film on mild steel in $\mathrm{CO}_{2}$ environments”, Houston: Nace International, n. 2511, 2009.

[12] TAMURA H., "The role of rusts in corrosion and corrosion protection of iron and steel", Corrosion Science, v. 50, pp. 1872-1883, 2008.

[13] MCNEILL L.S., EDWARDS M., "Iron pipe corrosion in distribution systems", J. Am. Water Works Assoc, v. 93, pp. 88-100, 2001.

[14] XIE Y., JIANG J.J., TUFA K.Y., et al., "Wear resistance of materials used for slurry transport", Wear, pp. 332-333, 2015.

[15] BOOTLE M., "Wear in rotodynamic (centrifugal) slurry pumps", In: Calgary Pump Symposium, November, 2009.

[16] PREECE, C.M., “Cavitation erosion”, In: Treatise on Materials Science and Technology: Erosion in Academic Press, v. 16, pp. 24-308, 1979.

[17] LIANG, J, DENG, A, XIE, R, et al., "Impact of flow rate on corrosion of cast iron and quality of remineralized seawater reverse osmosis (SWRO) membrane product water", Desalination, v. 322, pp. 76-83, 2013.

[18] COPSON H.R., "Effects of velocity on corrosion”, Corrosion, v. 16, pp. 86-92, 1960.

[19] ELIASSEN R., PEREDA C., ROMEO A.J., SKRINDE R.T., "Effects of pH and velocity on corrosion of steel water pipes", Water Works Assoc, v. 48, pp. 1005-1018, 1956.

[20] ANDRADE C.A., "Identificação dos mecanismos de corrosão nos oleodutos que transportam o petróleo cabiúnas e definição de critérios para determinar os agentes corrosivos e a corrosividade interna de oleodutos", CENPES/DIPLOT/SEMEC, Rio de Janeiro, 2000.

[21] GENTIL, V., Corrosão, Rio, Ltc, 2007.

[22] SILVA, F. N., CUNHA, J.D., LIMA, F.F., et al., "Corrosive-cavitative-erosive wear of a carbon steel in aqueous medium with salt $(\mathrm{NaCl}), \mathrm{CO}_{2}$ and solid particulates $\left(\mathrm{SiO}_{2}\right)$ fractions", In: The 5th World Tribology Congress - International, Torino, Italy, pp. 8-13, 2013.

[23] RUZIC V., VEIDT M., NEŠIĆ S., "Protective iron carbonate films - part 1: mechanical removal in single-phase aqueous flow", Corrosion, v. 62, n. 5, pp. 419-432, 2006.

[24] SILVERMAN D.C., WINSTON R., "Practical corrosion prediction using electrochemical techniques", In: Winston Revie R., Editor. UHLIG'S Corrosion Handbook, 3 ed, Hoboken, John Wiley \& Sons, 2011.

[25] AMERICAN SOCIETY FOR TESTING AND MATERIALS - ASTM. ASTM G185-06: Standard practice for evaluating and qualifying oil field and refinery corrosion inhibitors the rotating cylinder electrode, West Conshohocken. 


\section{ORCID}

Fernando Nunes da Silva https://orcid.org/0000-0003-1378-8864

Plínio Melo de Oliveira https://orcid.org/0000-0002-7250-7084

Nícolas Matheus da Fonseca Tinoco de Souza Araújo - https://orcid.org/0000-0003-4436-9769

Eugênio Teixeira de Carvalho Filho https://orcid.org/0000-0001-8451-9747

Jardel Dantas da Cunha

http://orcid.org/0000-0002-9449-6611

Djalma Ribeiro da Silva

https://orcid.org/0000-0001-6902-149X

João Telésforo Nóbrega de Medeiros https://orcid.org/0000-0002-2665-7428 